


\section{Water quality and Safety of potable water wells in Gjakova region, Kosovo}

Antigona Ukehaxhaj 1,3, Dardan Koçinaj1*, Arben Boshnjaku1, Naser Ramadani 3 , Drita Zogaj3, Roza Allabashi 2

${ }^{1}$ University "Fehmi Agani" of Gjakova, Kosovo

${ }^{2}$ University of Natural Resources and Life Sciences, Vienna; Department of Water, Atmosphere, Environment, Institute of Sanitary Engineering and Water Pollution Control, Vienna, Austria

${ }^{3}$ National Institute of Public Health-Centre for Laboratory Testing

*Corresponding Author: Dardan Kocinaj

\section{Abstract}

Introduction: At a basic level, everyone needs access to safe water in adequate quantities for drinking, cooking, personal hygiene and sanitation facilities, and it is a fundamental requirement for good health and also a human right.

Methods: The study is conducted from the University of Gjakova and performed in collaboration with drinking water authority National Institute of Public Health and other local authorities in Kosovo. Water samples were transported from 20 samples to the laboratory at a temperature of $\left(4-5^{\circ} \mathrm{C}\right)$. The analysis of chemical and microbiological parameters is performed according to international standard methods (ISO methods). Detection of heavy metals in drinking water is performed by ICP-MS according to EPA $6020 \mathrm{~A}$.

Results: from 30 physical chemical parameters very high ammonium concentrations $(2.6 \mathrm{mg} / \mathrm{l}$ and higher) are observed in two water wells, which is a common indicator of anthropogenic impact through organic waste disposal, leaking sewage systems or animal waste pollution. This could be 
confirmed for the well "Blloku i Ri Orize", where the total number of coliform bacteria of faecal origin is significantly higher than the national limit.

Similar situation could be observed for the Qifllak well, which shows the highest microbiological contamination (values $>300 \mathrm{cfu} / 100 \mathrm{ml}$ for all four analysed parameters) and a significantly higher ammonium concentration compared to the other samples $(0.182 \mathrm{mg} / \mathrm{l}$ compared to the median $0.013 \mathrm{mg} / \mathrm{l})$.

Conclusion: Studies of microbial contamination and sanitary risk could be improved by adhering to higher standards, including those outlined in our quality criteria.

Keywords: potable water well, water quality, drinking water, monitoring, public health 


\section{Introduction}

Safe and good quality water is one of the most important human needs, whereas the quality of drinking water is one of the greatest factors affecting human health. ${ }^{1}$

A reliable, safe water supply plays an important role in disease prevention, especially by facilitating personal, domestic, and food hygiene. It has been reported that only around $71 \%$ of the total world population are using a safely managed drinking-water service, whereas at least 2 billion people globally are using a water source contaminated with faeces. ${ }^{2}$

Elsewhere in the developed world, the general interest has shifted significantly, with the demand for bottled water having undergone a consistent increase during the last decade (in particular), transforming the bottled water industry into the fastest growing segment within the global non-alcoholic beverage market ${ }^{3}$. This behaviour comes with significant consequences, given that the bottled water can cost on average 50-100 times more per litre than tap water, and does not guarantee a better quality than the tap water. Notwithstanding, the risk of acquiring a waterborne infection increases with the level of contamination by pathogenic microorganisms. Other agents, however, such as Salmonella typhi, Vibrio cholerae, Giardia lamblia and hepatitis A virus, are frequently transmitted via contaminated drinking-water.,

It is estimated that $80 \%$ of all diseases and over one-third of deaths in developing countries are caused by the consumption of contaminated water and on average as much as one-tenth of each person's productive time is sacrificed to water-related diseases.

The World Health Organisation (WHO) as a United Nations (UN) specialized agency responsible to protect the international public health, produces international guidelines for the quality of drinking-water that are used as the basis for setting standards and regulations in both developing and developed countries.Yet, countries consider different environmental, cultural, social and economic factors when determining the guidelines to adopt as their own standards. ${ }^{5}$

A recent nationwide survey by the U.S. Environmental Protection Agency and Cornell University found that contamination of drinking water by septic tank effluents may be one of the foremost water-quality problems in the Nation. ${ }^{6}$ It is estimated that up to 1.9 million people worldwide rely on water from "unimproved" sources or 'improved' sources that are fecal contaminated. Of the water-associated infections, diarrhea continues to be a leading child-killer globally, despite a 
decrease in under-five deaths by nearly $50 \%$ between 2000 and 2013. Diarrheal infections disproportionately affect children living in Low- and Middle-Income Countries. $^{7}$

Other drinking water contaminants are nitrate and nitrite, which are present in chemical fertilizers, domestic waste water and animal waste. They can reach potable water well through groundwater, surface water and water run-off. High levels of nitrate/nitrite in drinking water can cause methemoglobinemia or "blue baby syndrome". These substances reduce the blood's ability to carry oxygen. Infants below six months who drink water with high levels of nitrate can become seriously ill. ${ }^{8}$

The following conditions may also put people at higher risk of developing nitrate-induced methemoglobinemia: anaemia, cardiovascular disease, lung disease, sepsis and metabolic problems. ${ }^{9}$

The water quality standards are laid down in the drinking water Directive 98/83/EC, which is applied to all public and private water supplies intended for drinking, food preparation and other domestic purposes. The quality standards for chemical and bacteriological parameters, as well as the methods of analysis are described by the Administrative Instruction 16/2012, which is obligatory in Kosovo. According to these standards, water intended for human consumption must be free from organisms and from concentrations of chemical substances that may be a hazard to health. Temperature, absence of turbidity, and absence of colour and of any disagreeable taste or smell are of the utmost importance in public supplies of drinking-water. ${ }^{10,11}$

Private wells are normally not subject to the mentioned standards and monitoring programmes, but the government has to set rules to protect their users from health hazards. Unlike public drinking water systems, private wells are not included in regular monitoring programs regarding water quality. In general, the owners are responsible for ensuring good water quality, to protect their own health. Properly designed and constructed wells, normally are able to supply sufficient and safe water for at least a single household. ${ }^{12,13,14}$

The results of this study are considered an important contribution to improving the lack of information about the quality of the potable water wells in the area and identification of possible pollution sources. Communication of these results with the community will help in raising the awareness on drinking water quality issues and the necessity of periodic quality controls of potable water wells to ensure safe drinking water. 


\section{Materials and Methods}

\section{Study area}

The study is conducted from the University of Gjakova and performed in collaboration with drinking water authority "National Institute of Public Health" which is the authorized institution for water quality control in Kosovo.

The Dukagjini region is the flat part of the Western region of the Republic of Kosovo. It lies in a length of $70 \mathrm{~km}$ and a width of $43 \mathrm{~km}$. The Municipality of Gjakova is an administrative unit with a geographical position of $42.39^{\circ}$ north, $20.43^{\circ}$ east. The Municipality of Gjakova is supplied with water from the Lake "Radoniqi" in an area of 580 ha, at an altitude of 400-456.4 m and ranks second in Kosovo in terms of area. The main supplier of the lake is the river Deçan and the river Përrua of Ratisha. $^{15}$

Municipality of Gjakova has a population of 115,859 inhabitants. (Statistical Office of Kosova 2015). ${ }^{16}$ From all of them, $78 \%$ have access to water supply from Radoniqi Water Company, $6 \%$ are provided from other distribution systems and $16 \%$ have no access to any operational water supply system. Accordingly, approximately 27.350 people in the Municipality of Gjakova use drinking water from individual wells.

The sampling process is performed from staff of University of Gjakova, with strong involvement of the users' community. Ethical permission has already been obtained for this study.

Based on all the facts mentioned, this study aims to perform a monitoring study in rural areas of the municipality of Gjakova (those areas not connected to public water supply) including chemical, microbiological and toxicological analysis.

Well water was exclusively used for drinking and other household uses,the wells are also mostly used for other activities (laundry,shower, etc), animal watering and irrigation.

The study is focused on monitoring indicators for faecal pollution, along with the common physical-chemical parameters, and specific pollutants like pesticides and heavy metals, as defined in the respective national and European regulations.

The study was conducted in Gjakova, in total there are 20 water samples collected from potable water wells in rural areas, as shown in Figure 1, in depth between 5 to 
40 m. They include Gjakova, Blloku i Ri Orize, Marmul, Ramoc, Rracaj, Rrypaj, Dobrosh, Piskote, Kramovike, Qifllak, Zhabel, Jabllanice, Bardhaniq, Popoc, Ponoshec and Raqe.

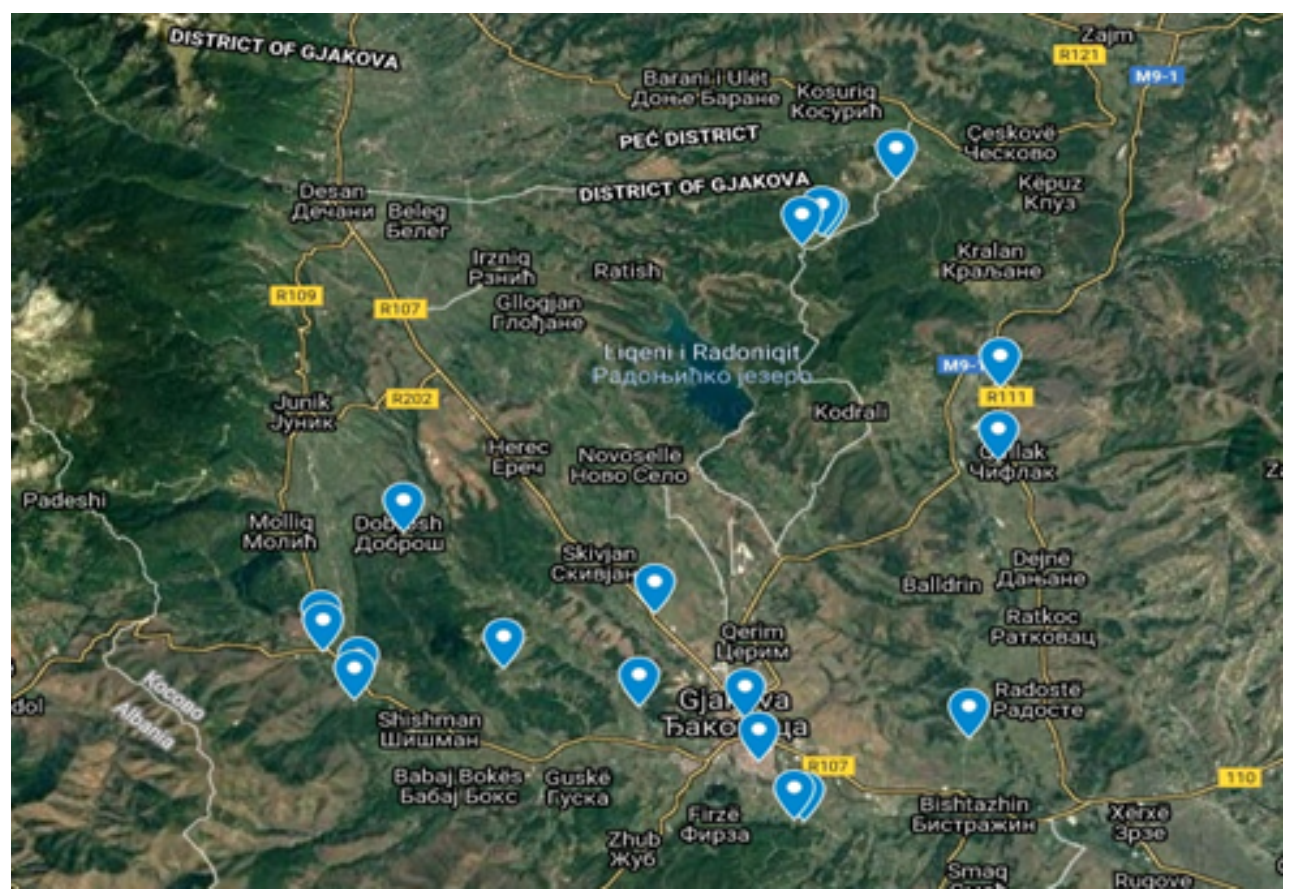

Figure 1 Map of sampling points

\section{Sample collection}

Water samples for physical-chemical analysis are collected in purified $2000 \mathrm{~mL}$ bottles. Water samples for pesticides, heavy metals were transported in cleaned and tightly sealed glass bottles. Water samples for microbiological analyses are collected in sterile $500 \mathrm{~mL}$ glass bottles. The water was taken from wells or taps that were connected to the well water and before sampling, the water was allowed to flow at a time interval of 15 minutes. The sample was kept sterilized bootless in an ice chest and transported to the laboratory at a temperature of $4-5^{\circ} \mathrm{C}$. The bacteriological tests were undertaken within $6 \mathrm{~h}$ of collection to avoid death or growth of organisms in the sample. 
Sample analysis procedure

Bacteriological analysis

Bacteriological quality is one of the important parameters of water potability. E-coli is one of the most determined bacteria that indicates faecal contamination. ${ }^{17}$

Total coliform and faecal coliform colonies were counted after $24 \mathrm{~h}$ of incubation at a temperature of $37^{\circ} \mathrm{C}$ to total germs and $44^{\circ} \mathrm{C}$, respectively, using membrane filtration and membrane lauryl sulphate broth methods. Tests were conducted using $100 \mathrm{ml}$ of water aseptically filtered through a nitrocellulose filter. After filtration, this membrane was placed in a Petri dish containing a standard culture medium TTC (trifenyl chloride tetrazolium) and Tergitol for total germs and E-coli.

The results were collected 48-72 hours after incubation. Yellow colonies for both total coliform and faecal coliform were counted using the colony counter.

The results are analyzed by considering the bacteriology for the detection and enumeration of faecal bacteria in water of the Drinking Water Directive 98/83/EC and Administrative Instruction No. 16/2012 which is obligatory for drinking water quality in Kosovo.

Physicochemical analysis

Water temperature was measured on the site using mercury thermometer, $\mathrm{pH}$ was measured using digital $\mathrm{pH}$ meter (ISOLAB). Turbidity was measured by Hanna using 1.2-2.4 NTU Standards. Hardness, residual chlorine are measured with volumetric methods and the other physicochemical parameters were measured with Photometer NOVA 60 A.

Analysis of heavy metals is performed by ICP-MS according to EPA $6020 \mathrm{~A}$. Determination of Organ chlorine pesticides / $0.1 \mathrm{mcg} / \mathrm{I}$ was measured with GC SHIMADZU 2010, ECD. 
Journal of Science, Humanities and Arts

\begin{tabular}{|c|c|c|c|}
\hline Partameter tested & Standard Method & $\begin{array}{c}\text { Measuring } \\
\text { unit }\end{array}$ & Measuring Range \\
\hline Odor & $802892-15$ & & \\
\hline Color & $1507887: 1994$ & $m \cdot 1$ & \\
\hline Mardnes & 1506059.1984 & $8 \mathrm{H}$ & $01-50$ \\
\hline Free chlorine (residue) & $1507393 \cdot 1: 2000$ & $\mathrm{ma} / \mathrm{l}$ & $0.018 \cdot 15$ \\
\hline Chlorides & 1509297:1989 & $\mathrm{me} / 1$ & 5.250 \\
\hline Turbidiny & 15070272001 & NTU & $0.01 \cdot 2000$ \\
\hline $\mathrm{Ph}$ & 15010523:2008 & & $10-14.0$ \\
\hline Conductivity & 150278882.2001 & $\mu \mathrm{s} / \mathrm{km}$ & 001,2500 \\
\hline Irontfe & SMMWW3SOOFe-8 8 & $\mathrm{~m} / \mathrm{l}$ & $0.005-50$ \\
\hline Marganese-Mn & 1506333:1986 & $m / \sqrt{l}$ & $0.01 \cdot 10.0$ \\
\hline Aluminium $-A$ I & SMWW3SOO-AI & $\mathrm{mg} / \mathrm{l}$ & 0.0201 .20 \\
\hline Sulphate-5042 & SMMWW4500-504 & $\mathrm{mg} / \mathrm{l}$ & 10.250 \\
\hline Ammonia - $\mathrm{NH}_{4}{ }^{*}$ & $1507150-1: 2966$ & $\mathrm{ma} / \mathrm{l}$ & $0.01-30$ \\
\hline Nitrte- NO, & $1506 \mathrm{m7}: 1934$ & $\mathrm{mg} / \mathrm{l}$ & $0,002-100$ \\
\hline Nitrate- NO, & 1507890-3:1988 & $m g / 1$ & 0.20 .20 .0 \\
\hline Det. of permanzan indx.(0) & $1508467: 2000$ & $\mathrm{mg} / 1$ & $0.5-10$ \\
\hline Calcium - $\mathrm{Ca}$ & 1506059.19845 & $m=/ 1$ & 0.05 .250 \\
\hline Carten disoxide $-\mathrm{CO}_{2}$ & SMWWASOOCO, & $m$ & 400.7380 \\
\hline Magnesium + Me & 1506059.1594 & $m g / 1$ & 0.05 \\
\hline Nitrogen - N & SMWWASOONN & $\mathrm{mg} / \mathrm{l}$ & $0.5-15$ \\
\hline Oxyzen $-\mathrm{O}_{2}$ & SMWW 27100 & $0, m e / 1$ & 0.0 .19 .9 \\
\hline Phenols & SMaWWSs3af & $m / 1$ & $0.001-0.25$ \\
\hline Phosphorusp & SMWW4SOOPOQ & $\mathrm{m} / \mathrm{d}$ & $0.01-5.0$ \\
\hline Filuoride & SMMWUSOO-F.E & $\mathrm{mg} / \mathrm{l}$ & 0.10 .15 \\
\hline Cyanide & SMWWWSO0Cn & $\mathrm{me} / \mathrm{l}$ & $0,002-050$ \\
\hline Bilarbonate $\mathrm{HCO}_{3}$ & $5 M W W 2320-8$ & $\mathrm{mel}$ & - \\
\hline Carbonate $-\mathrm{CO}_{2}$ & $5 M W W 2320-8$ & $\mathrm{me} / \mathrm{l}$ & - \\
\hline lodine-s & SMMWUSOOH & $m / / 1$ & $m$ \\
\hline Fotal Organic tanen - $\mathrm{T} \propto \mathrm{C}$ & EU-En1484:1997 & $\mathrm{me} / \mathrm{l}$ & $0.50-10.0$ \\
\hline Distived ortanik carben - DOC & EU-EN 1484:1997 & $\mathrm{me} / \mathrm{l}$ & $0.50-10.0$ \\
\hline Total Organochiorine Pesticides & EPA methods $8081 \mathrm{~A}$ & $\mathrm{mg} / 1$ & 0.002 .0 .1 \\
\hline Total Susgended Solids & SMWW 25400 & $m / \sqrt{l}$ & $0.1-50$ \\
\hline Bromate BrO, & $15015061-1995$ & $\mathrm{~m} / \mathrm{l}$ & $0.003-0.120$ \\
\hline Total Colform bacteria & 1509385.1:2003 & in $100 \mathrm{ml}$ & \\
\hline Coliform Bacteris of foecal criph & 150.9383:1:2003 & in $200 \mathrm{ml}$ & \\
\hline $\begin{array}{c}\text { Total number of aerobic mesophylic } \\
\text { bacteria }\end{array}$ & 15062221999 & in $100 \mathrm{ml}$ & \\
\hline Streatococous of fe acal origin & $1807899-22000$ & in $100 \mathrm{ml}$ & \\
\hline Sulpide reducing annerobis bacteris & & in $100 \mathrm{ml}$ & \\
\hline Pexudomonas aeruginosa & & in $100 \mathrm{ml}$ & \\
\hline
\end{tabular}

Results and discussions 
Physical-chemical parameters

Nearly 30 chemical physical parameters are analysed in total in water samples from 20 potable water wells, in rural places in Municipality of Gjakova during April 2020. For parameters cyanide, iodine, turbidity and phenols the concentration in all samples was shown to be lower than the limit of detection of the analytical method. The other parameters are summarized in Table 2. As it can be seen in this table, most of the samples are following the national regulation for the water quality for human consumption.

Table 2 Selected chemical-physical parameters, their median values in all water wells and comparison with the national regulation 


\begin{tabular}{|c|c|c|c|c|}
\hline Parameter & Unit & Complies [n, (\%)] & Median values & $\begin{array}{l}\text { Limits according to } \\
\text { national regulation }\end{array}$ \\
\hline Ammonium (NH4) & $\mathrm{mg} / \mathrm{l}$ & $18(90 \%)$ & 0.013 & 0.5 \\
\hline Bicarbonate ( $\mathrm{HCO} 3)$ & $\mathrm{mg} / \mathrm{l}$ & $\ldots$ & 36.7 & $\ldots$ \\
\hline Carbonate (CO3) & $\mathrm{mg} / \mathrm{l}$ & $\ldots$ & 18 & $\ldots$ \\
\hline Chloride (CI) & $\mathrm{mg} / \mathrm{l}$ & $20(100 \%)$ & 7.5 & 250 \\
\hline Color & $\mathrm{m}^{-1}$ & $20(100 \%)$ & & $\ldots$ \\
\hline Conductivity & $\mu \mathrm{S} / \mathrm{cm}$ & $20(100 \%)$ & 360 & 2500 \\
\hline Fluorine (F) & $\mathrm{mg} / \mathrm{l}$ & $20(100 \%)$ & 0.05 & 1.5 \\
\hline Hardness & "dH & $20(100 \%)$ & 11.42 & $\ldots$ \\
\hline Iron & $\mu \mathrm{g} / \mathrm{l}$ & $20(100 \%)$ & 0.001 & 200 \\
\hline Manganese & $\mu \mathrm{g} / \mathrm{l}$ & $20(100 \%)$ & 0.001 & 50 \\
\hline Nitrate (NO3) & $\mathrm{mg} / \mathrm{l}$ & $20(100 \%)$ & 3.36 & 50 \\
\hline Nitrite (NO2) & $\mathrm{mg} / \mathrm{l}$ & $20(100 \%)$ & 0.00495 & 0.5 \\
\hline Oxygen consumption & $\mathrm{mg} / \mathrm{l}$ & $20(100 \%)$ & 0.86 & 5 \\
\hline Oxygen content (O2) & $\mathrm{mg} / \mathrm{l}$ & - & 4.29 & $\ldots$ \\
\hline pH & - & $20(100 \%)$ & 7.58 & $6.5-9.5$ \\
\hline Phosphate (PO4) & $\mathrm{mg} / \mathrm{l}$ & $19(95 \%)$ & 0.02 & 1.5 \\
\hline Smell & $\ldots$ & $20(100 \%)$ & & $\ldots$ \\
\hline Sodium & $\mu \mathrm{g} / \mathrm{l}$ & $20(100 \%)$ & 0.001 & 200 \\
\hline Sulphate (SO4) & $\mathrm{mg} / \mathrm{l}$ & $20(100 \%)$ & 3.55 & $0-250$ \\
\hline TOC & $\mathrm{mg} / \mathrm{l}$ & $\ldots$ & 2.66 & $\ldots$ \\
\hline
\end{tabular}

In the study done by Abdolmajid Fadaei et al (2014), the $\mathrm{pH}$ value of the water ranged from 6.62 to 8.72 (mean $7.60+/-0.21$ ). The $\mathrm{PH}$ was below the Administrative instruction and EU directive acceptable level. ${ }^{18}$ Similar with our finding the studies carried out by $\mathrm{H}$. Adamou et al (2020), almost all samples had $\mathrm{pH}$ value within the WHO recommends. They also find abnormal concentrations of $\mathrm{NO}_{2}$ and $\mathrm{NO}_{3}$ in almost half of analysed samples, which may have great danger for the population, especially for the juvenile population. ${ }^{19}$ High nitrate concentrations are reported in some groundwater studies in Nigeria, Morocco and Togo. ${ }^{20,21,22}$ The $\mathrm{pH}$ of drinking water has no immediate direct effects on human health but has some indirect health effects by bringing changes in other water quality parameters such as solubility of metals and survival of pathogens. (Zabed et al,2014). ${ }^{23}$ The turbidity value is below the permissible limits of 0.4-2.5 NTU. The analysis of free chlorine in all water wells show concentrations lower than limit of detection of the analytical method, confirming that no water disinfection is performed at all. The standards authorized by Administrative Instruction in Kosovo (16/2012) in drinking water for ammonium concentration are $0-0.5 \mathrm{mg} / \mathrm{l}$. Very high ammonium concentrations $(2.6 \mathrm{mg} / \mathrm{l}$ and higher) are observed in two water wells (Blloku Ri Orize \& Marmul). These values strongly exceed the median of all collected samples $(0.013 \mathrm{mg} / \mathrm{l})$ and the limit of the national regulation of $0.5 \mathrm{mg} / \mathrm{l}$. High ammonium concentrations in potable water wells are a common indicator of anthropogenic impact through organic waste disposal, leaking sewage systems or animal waste pollution. This could be confirmed for the well "Blloku i Ri Orize", where the total number of coliform bacteria of faecal origin is significantly higher than the national limit. Additionally, both parameter TOC and oxygen demand in this sample show the highest values among all (6.1 and $3.4 \mathrm{mg} / \mathrm{l}$ respectively), confirming a very high bacterial load. Furthermore, the extremely high concentration of phosphate in this sample (1.55 $\mathrm{mg} / \mathrm{l}$ ) compared to the other samples (median: $0.02 \mathrm{mg} / \mathrm{l}$ ) is an additional 
confirmation for organic waste contamination as phosphorus is a common constituent of manure, and organic wastes in sewage and industrial effluent. Similar situation could be observed for the Qifllak well, which shows the highest microbiological contamination (values $>300 \mathrm{cfu} / 100 \mathrm{ml}$ for all four analysed parameters) and a significantly higher ammonium concentration compared to the other samples $(0.182 \mathrm{mg} / \mathrm{l}$ compared to the median $0.013 \mathrm{mg} / \mathrm{l})$. During the sampling, it was observed that the well was very shallow and poorly protected, so that surface water could easily penetrate into the well. Consequently, it can be concluded that these two potable wells are highly contaminated (chemically and microbiologically) and the source of contamination is probably leakage of waste water from sewage or animal waste. In the water sample from well "Marmul" on the contrary, though high ammonium concentration, no significant microbiological contamination is observed, so that the reason for the high ammonium concentration cannot be faecal pollution. The high ammonium concentration in this sample can be explained with its high nitrogen content (nitrate $45.4 \mathrm{mg} / \mathrm{l}$ ) and its transformation to nitrite and ammonium under anaerobic conditions in this deep well $(30 \mathrm{~m})$. Both parameters are significantly increased in this sample (nitrite: $0.059 \mathrm{mg} / \mathrm{l}$ and ammonium $2.6 \mathrm{mg} / \mathrm{l}$ ), compared to the respective median values $(0.005 \mathrm{mg} / \mathrm{l}$ and $0.013 \mathrm{mg} / \mathrm{l})$. In this case, is supposed that the source of contamination is nitrate from agricultural use. Raised nitrogen levels in groundwater because of excessive usage of nitrogen-based fertilizers are known problems in many places in Europe. A team of scientists have recently calculated the dynamic of these fertilizers in groundwater, coming to the conclusion that nitrate can leach into the groundwater and surface water on about three-quarters of Europe's agricultural land over a period of at least four months per year. ${ }^{24}$ The standards authorized by Administrative Instruction in Kosovo (16/2012) in drinking water for nitrate are 0-50 $\mathrm{mg} / \mathrm{l}$. There are rather high nitrate concentrations (35 - 45mg/l) observed in four water wells (Marmul, Dobrosh, Zhabel (1) and Jabllanice), but they are still below the threshold given in the national regulation $(50 \mathrm{mg} / \mathrm{l})$. These samples are consequently showing higher nitrate-nitrite-index ([nitrate]/50+ [nitrite]/3), which must be lower than $1 \mathrm{mg} / \mathrm{l}$ according to the national regulation. The calculated values for these samples are not exceeding this threshold but are between 0.7 and $0.9 \mathrm{mg} / \mathrm{l}$, which indicates a rather high nitrogen content in water. This is supposed to be a consequence of excess usage of fertilizers in this area. This is consistent with the studies carried out by Abdolmajid Fadaei et al (2014), where nitrate recorded a mean value of $15.5 \mathrm{mg} / \mathrm{l}$. Min $7.4 \mathrm{mg} / \mathrm{l}$ and Max is $25.6 \mathrm{mg} / \mathrm{l} .{ }^{18}$ Similar to our study done by H Adamou et al (2020) ${ }^{19}$, they had found at least twice the standard value for $\mathrm{NO}_{2}$ and $\mathrm{NO}_{3}$ concentrations. Most of these wells are shallow and poorly protected and can result in disease transmission. Studies have been focused on some main issues concerning well water, and those published about arsenic presence, bacteriological contamination, geological factors, health impact, public health importance, etc. Despite the law, the programs are used to increase the awareness of the households to test their water and contribute on public health. $2^{5,26}$ 


\section{Pesticides and heavy metals}

As already mentioned pesticides represent a serious contamination source for potable water wells as they can penetrate through waste disposal, wastewater spills, and surface water run-off. People that consume high levels of pesticides and other organic chemicals may suffer from damage to their kidneys, liver, circulatory system, nervous system, and reproductive system. The concentration level of pesticides measured in this study resulted to be very low in all investigated wells. In total 15 pesticides and their metabolites are analysed in 20 water samples. The concentration of total pesticides analysed resulted to be under the limit of quantification of the analytical method $(0.01-0.05 \mu \mathrm{g} / \mathrm{l})$ for every water sample. Even the concentrations of the single substances were under the limit of quantification, except one (Methoxychlor in the well "Blloku i ri Orize" with $0.02 \mu \mathrm{g} / \mathrm{l}$ ), it can be concluded that the potable wells investigated are well protected from the penetration of these pesticides from the agricultural land use in the region. To investigate the well water quality in terms of heavy metals, in total 13 elements are analysed in all water wells. For $\mathrm{Co}, \mathrm{Al}, \mathrm{As}, \mathrm{Se}, \mathrm{Sb}, \mathrm{Hg}, \mathrm{Ag}$ no concentrations higher than the limit of quantification of the analytical method could be detected in For Co, $\mathrm{Al}, \mathrm{As}, \mathrm{Se}, \mathrm{Sb}, \mathrm{Hg}, \mathrm{Ag}$ no concentration higher than the quantity limit of the analytical method expressed in $\mu \mathrm{g} / \mathrm{l}$ of water can be detected. The results for $\mathrm{Ni}, \mathrm{Cr}$, $\mathrm{Cd}, \mathrm{Mn}$, Fe and $\mathrm{Zn}$ and the corresponding threshold values within recommended standards are shown on Table 3.

Table 3 Heavy metal concentration and the corresponding threshold from the national regulation in $\mu \mathrm{g} / \mathrm{l}$ 


\begin{tabular}{|c|c|c|c|c|c|c|c|}
\hline Water well & Well depth & Ni & Cr & Cd & Mn & Fe & Zn \\
\hline Gjakova & $7 \mathrm{~m}$ & $<\mathrm{LOQ}$ & $<\mathrm{LOQ}$ & 0,07 & 0,70 & 1,29 & 244 \\
\hline Blloku i ri Orize & $40 \mathrm{~m}$ & 1,62 & $<\mathrm{LOQ}$ & $<\mathrm{LOQ}$ & 104 & 8,33 & 20,1 \\
\hline Marmul & $30 \mathrm{~m}$ & $<\mathrm{LOQ}$ & $<\mathrm{LOQ}$ & $<\mathrm{LOQ}$ & 10,2 & 1,05 & 15,3 \\
\hline Ramoc & $15 \mathrm{~m}$ & $<\mathrm{LOQ}$ & 0,25 & 0,21 & 0,34 & 5,72 & 12,6 \\
\hline Rracaj & $7 \mathrm{~m}$ & $<\mathrm{LOQ}$ & $<\mathrm{LOQ}$ & $<\mathrm{LOQ}$ & $<\mathrm{LOQ}$ & 1,94 & 11,1 \\
\hline Rrypaj & $6 \mathrm{~m}$ & $<\mathrm{LOQ}$ & $<\mathrm{LOQ}$ & $<\mathrm{LOQ}$ & 0,48 & 0,66 & 31,7 \\
\hline Dobrosh & $22 \mathrm{~m}$ & $<\mathrm{LOQ}$ & $<\mathrm{LOQ}$ & $<\mathrm{LOQ}$ & 4,66 & 3,66 & 60,7 \\
\hline Piskote & $7 \mathrm{~m}$ & $<\mathrm{LOQ}$ & $<\mathrm{LOQ}$ & $<\mathrm{LOQ}$ & 8,60 & $<\mathrm{LQ}$ & 30,9 \\
\hline Kramovike & $3-4 \mathrm{~m}$ & $<\mathrm{LOQ}$ & $<\mathrm{LOQ}$ & $<\mathrm{LOQ}$ & 1,57 & 3,15 & 9,7 \\
\hline Qifllak & $5 \mathrm{~m}$ & $<\mathrm{LOQ}$ & $<\mathrm{LOQ}$ & $<\mathrm{LOQ}$ & 7,73 & 4,92 & 11,0 \\
\hline Zhabel-1 & $5.5 \mathrm{~m}$ & $<\mathrm{LOQ}$ & $<\mathrm{LOQ}$ & $<\mathrm{LOQ}$ & 2,77 & 4,11 & 149 \\
\hline Zhabel-2 & $6 \mathrm{~m}$ & $<\mathrm{LOQ}$ & $<\mathrm{LOQ}$ & $<\mathrm{LOQ}$ & 8,89 & 2,37 & 22,5 \\
\hline Jabllanice & $13 \mathrm{~m}$ & $<\mathrm{LOQ}$ & $<\mathrm{LOQ}$ & $<\mathrm{LOQ}$ & 30,4 & 2,09 & 11,4 \\
\hline Bardhaniq & $7 \mathrm{~m}$ & $<\mathrm{LOQ}$ & $<\mathrm{LOQ}$ & $<\mathrm{LOQ}$ & 71,9 & 2,55 & 5,9 \\
\hline Popoc-1 & $14 \mathrm{~m}$ & $<\mathrm{LOQ}$ & $<\mathrm{LOQ}$ & $<\mathrm{LOQ}$ & 3,28 & 4,96 & 3,5 \\
\hline Popoc-2 & $22 \mathrm{~m}$ & $<\mathrm{LOQ}$ & $<\mathrm{LOQ}$ & $<\mathrm{LOQ}$ & 0,73 & 10,9 & 331 \\
\hline Ponoshec-1 & $7 \mathrm{~m}$ & $<\mathrm{LOQ}$ & $<\mathrm{LOQ}$ & $<\mathrm{LOQ}$ & 0,80 & 1,08 & 1,8 \\
\hline Ponoshec-2 & $8 \mathrm{~m}$ & $<\mathrm{LOQ}$ & $<\mathrm{LOQ}$ & $<\mathrm{LOQ}$ & 0,47 & 1,32 & 9,2 \\
\hline Raqe-1 & $5 \mathrm{~m}$ & $<\mathrm{LOQ}$ & $<\mathrm{LOQ}$ & $<\mathrm{LOQ}$ & 3,10 & 1,25 & 30,8 \\
\hline Rage-2 & $8 \mathrm{~m}$ & $<\mathrm{LOQ}$ & $<\mathrm{LOQ}$ & $<\mathrm{LOQ}$ & 0,59 & 2,54 & 27,6 \\
\hline Threshold & & 20 & 50 & 5 & 50 & 200 & 3000 \\
\hline & & & & & & \\
\hline
\end{tabular}

As it can be seen on this table, the measured concentrations of $\mathrm{Ni}, \mathrm{Cr}, \mathrm{Cd}$ in three samples (all the others are $<\mathrm{LOQ}$ ) are very low compared to the corresponding threshold values. The same conclusion can be reached for iron and zinc. In case of manganese there are two water samples exceeding the threshold value of $50 \mu \mathrm{g} / \mathrm{l}$, from wells Blloku i ri Orize and Bardhaniq. Based on this research we can conclude that the potable waters wells investigated in this study do not show any kind of heavy metal contamination. Similar to our study we found the findings in research from Abdolmaid and al (2014), ${ }^{18}$ where the As, Zn, Cu, Se, Cr, Mo, Sb and V contents were found below the permissible limit.

Microbiological analysis

In countries with low income such as Kosovo, the majority of the population is not adequately supplied with safe drinking water and quality from network water supply, that's why they use well water for drinking, domestic and other purposes. Unfortunately their wells are unprotected and ill- managed from individual households and may be unsafe for drinking and domestic application as a result of contamination through different sources of pollution. The most common water quality problem in rural water supply in Gjakova is bacterial contamination with Escherichia Coli, Streptococcal bacteria with fecal origin, coliform bacteria with fecal origin and mesophyll bacteria where from total 20 samples 5 are contaminated. Table 4 illustrates the relationship between the levels of bacteriological contaminants detected in the well in relation to the improper way of 
building wells and their improper depth. Another reason is the non-treatment of these resources neither by the municipal level nor by the owners of their use.

\section{Table 4. Micro-biological analysis}

\begin{tabular}{|c|c|c|c|c|}
\hline Escherichia coli* & $\begin{array}{l}\text { Complies [n, (\%)] } \\
19(95 \%)\end{array}$ & $\begin{array}{l}\text { Values }(\mathrm{mg} / \mathrm{l}) \\
15.50 \pm 67.00\end{array}$ & $\begin{array}{l}\text { Excessive levels } \\
\text { (fold) } \\
\quad 1.55\end{array}$ & $\begin{array}{l}\text { Limits } \mathrm{Ks} \\
\text { regulation }[\mathrm{mg} / \mathrm{l}] \\
0-10\end{array}$ \\
\hline $\begin{array}{l}\text { Enterococcus* } \\
\text { Coliform } \\
\text { bacteria* }\end{array}$ & $\begin{array}{l}18(90 \%) \\
15(75 \%)\end{array}$ & $\begin{array}{l}20.00 \pm 69.58 \\
43.68 \pm 95.46\end{array}$ & $\begin{array}{r}20 \\
4.37\end{array}$ & $\begin{array}{l}0 \\
0-10\end{array}$ \\
\hline $\begin{array}{l}\text { Total number of } \\
\text { live bacteria }\end{array}$ & $17(85 \%)$ & $70.00 \pm 107.31$ & $\mathrm{~N} / \mathrm{A}$ & $0-100$ \\
\hline
\end{tabular}

*in $100 \mathrm{ml}$ water

Most of these wells are shallow and poorly protected and can result in disease transmission. Studies have been focused on some main issues concerning well water, and those published about arsenic presence, bacteriological contamination, geological factors, health impact, public health importance, etc. Despite the law, the programs are used to increase the awareness of the households to test their water and contribute to public health. $2^{7}$ Furthermore, some authors found that they tend not to test their own wells. The positive samples for Escherichia Coli are found at a high number, and for the purpose of these highly contaminated wells and boreholes, the recommendations are to treat the water before consumptions. $2^{8}$ The contamination (Escherichia Coli and other resistant bacteria) is related to the use of dug or shallow wells and alerts the immediate action toward sanitation improvement and coordinate the public health policies. ${ }^{29}$

Similar to our study a study done in Brazilian cities by Nayara Maran et al during 2016, found that $33 \%$ of the water was contaminated with E.coli. ${ }^{28}$ Also a very valuable study done in Bekasi City shows that contamination of well water has 
occurred in $24 \%$ of samples taken poses a very high risk of contamination with E.coli. ${ }^{30}$ Based on another study done in 2018, it is clear that the presence of Escherichia coli is not detected in most of the analysis, but it was present in samples collected in the rainy season. ${ }^{31}$ Presence of Escherichia coli, clostridium perfringens, and staphylococcus aureus was found as well in another study in Kenia with $36.8 \%$ of the 20 surface water samples tested negative, but in $22.9 \%$ of the ground water sources were positive in this three bacteria. ${ }^{32}$ From another study in South Africa research showed the positive correlation in a total 144 samples, where all the wells sampled in this study recorded mean E.coli count above the WHO and the South African recommended limits for drinking water. ${ }^{33}$ Similar to our study a study done in Iran from Abdolmaid Fadaci et al (2014), found that total coliform bacteria in drinking water samples generally exceeded the permissible limit. That contamination may be due to leakage/discharge from septic tanks, lack of sewage and solid waste disposal systems which were the main threat to water sources. ${ }^{18} \mathrm{In}$ the study done by Jeremiah. $\mathrm{K}$ et al, (2018) in Ghana, were found to have bacteriological contaminations in relatively higher numbers of groundwater sources. From these contaminants in most of the samples non-faecal coliforms, salmonella, E.coli, and faecal coliforms were found. ${ }^{34}$ In recent study conducted in Nepal from (Rai et al., 2012), it was reported that out of the total 506 water samples studied $88,5 \%$ samples were positive for total coliform, whereas $56.5 \%$ were positive for faecal coliform particularly E.coli bacteria. ${ }^{35}$

\section{Conclusions}

From the results of the study, it can be concluded that according to our standards private potable water wells do not receive the same services as the public ones. In 
these cases the well owners are responsible for the quality of their drinking water and they must be aware of existing contamination potential and its possible health effects. Level of micro-bacterial contaminants were found in 5 samples and collected in rural areas in Municipality of Gjakova, for this reason these resources are not wholly safe for human consumption. The groundwater is not only faecal polluted but could also be potentially infectious, especially for children, the elderly and immunocompromised individuals. It is therefore recommended that water quality analysis be carried out on all wells in this area at least once a year to monitor the bacterial contaminations that were relatively high or low. In terms of chemical-physical parameters according to the results most of the samples (18 from 20) fit the national water quality regulation for human consumption and no serious problems with the chemical water quality could be identified. The water quality in two wells (Blloku i Ri Orize \& Marmul) is strongly contaminated with ammonium, exceeding the limit of the national regulation. This fact, in combination with the strong microbial pollution found in these wells leads to the conclusion of a strong anthropogenic impact through organic waste. In accordance with the observation that these wells were very shallow and bad protected, it can be concluded that the source of contamination is probably leakage of wastewater from sewage or animal waste. An enhancement of nitrate concentrations (35 - 45mg/l) is observed in four water wells. Even though these are still below the threshold given in the national regulation and no immediate measures are necessary. It is supposed to be a consequence of excess usage of fertilizers in this area. The analysis of free chlorine in all water wells shows concentrations lower than the limit of detection of the analytical method in every sample, confirming that no water disinfection is performed at any water well. This is important information in regard to microbiological water quality. From the analysis of 15 pesticides according to the national regulation in all samples, it can be stated that the concentration of total pesticides resulted to be under the limit of detection of the analytical method for every water well. Even the concentrations of the single substances were under the limit of quantification, with one single exception. Therefore, it can be concluded that the potable wells investigated are well protected from the penetration of these pesticides from the agricultural land use in the region. In terms of heavy metals, for most of them (Co, $\mathrm{Al}, \mathrm{As}, \mathrm{Se}, \mathrm{Sb}, \mathrm{Hg}, \mathrm{Ag}$ ) no concentrations higher than the limit of quantification of the analytical method could be detected in any of the samples. Only $\mathrm{Ni}, \mathrm{Cr}$ and $\mathrm{Cd}$ in three samples were detected, but their concentration is very low compared to the corresponding threshold values. The same conclusion can be done for iron and zinc. Manganese was the only metal exceeding the threshold value from the national regulation in two water samples. Based on these results, it can be concluded that the potable waters wells investigated in this study do not 
show any serious heavy metal contamination. The same research should be done in the winter season on purpose to raise awareness about the potential hazards of well water among local community leaders and empower many residents to test their water. This study highlights the need to involve users' communities at every single stage of drinking water supply using potable water wells, to ensure a long-term success on safe drinking water and health protection. Therefore, a large-scale distribution of water from the small drinking water supply system and the application of chemical disinfectants are alternative solutions for improving access to safe drinking water in rural areas, such as Gjakova. It is a strong responsibility of public health authority in Kosovo to raise this awareness and to make people change their behavior regarding drinking water protection in private potable water wells. As the risk is not the same for everyone but varies in complex ways depending on several dimensions (e.g., location, soil type, well structure) educational campaigns are of utmost importance and should be performed properly and regularly from the responsible authorities. Further extended studies regarding seasonal and regional variations in Kosovo are strongly recommended to achieve the above-mentioned goals.

\section{Author Contributions}

Announcements for individual contributions: idea, A.U. and R.A.; methods, A.U.; software, A.B.; validation, N.R., D.Z. and R.A.; writing-original draft preparation, A.U.; writing-review and editing, R.A.; idea, visualization, D.K.; funding achievement, A.U. All authors have read and agreed to the published version of the manuscript.

\section{Acknowledgement}

This work was supported by US Embassy Pristina - University Support Program for 2019/2020, Grant number US19 GR4 (Sustainable use of underground water resourses and safe drinking water in the municipality of Gjakova). 
We also acknowledge with appreciation the contribution of Prof. Roza Allabashi (Boku University of Vienna) for the constant support during this project and calculation process. 


\section{References:}

1. Li P, Wu J. Drinking water quality and public health. Exposure and Health. 2019. 11:73-79, https://doi.org/10.1007/s12403-019-00299-8.

2. WHO. Drinking-water. World Health Organization fact sheets, 2018.

3. Doria MF. Bottled water versus tap water: understanding consumers-preferences. J Water Health. 2006. 4:271-276.

4. Ferrier C. Bottled Water: Understanding a Social Phenomenon. AMBIO. A Journal of the Human Environment. 30(2):118-119, http://doi.org/10.1579/0044-7447-30.2.118.

5. Edzwald JK. Water Quality \& Treatment. A Handbook on Drinking Water. American Water Works Association. Sixth Edition. 2011. Mc Graw Hill;

6. Ground Water and the Rural Homeowner by Roger M. Waller, U.S. Department of the Interior / U.S. Geological Survey 1994.Denver

7. Mark Rohit Francis, Guru Nagarajan, Rajiv Sarkar, Venkata Raghava Mohan, Gagandeep Kang and Vinohar Balraj; Perception of drinking water safety and factors influencing acceptance and sustainability of a water quality intervention in rural southern India, Francis et al. BMC Public Health (2015) 15:731).

8. https://www.epa.gov/Potential Well Water Contaminants and Their Impacts, January 19,2017

\section{9. https://www.healthstate.mn.us.}

10. Rural water and sanitation Support Programme Kosovo, Phase IV; Coverage Study and Assessment of Water Supply and Sanitation System in Kosovo Financial and Technical assessment of independent non RWC managed rural supply systems, vol, 1 - Report CDI, 19.01.2012

11. Water quality control-Guideline for Kosovo, NIPH 1999.

12. Guidelines for drinking Water quality second edition, vol 3;Surveillance and control of community supplies,WHO,1997.Geneva Switzerland ISBN 9241545038.

13. Guidelines for drinking Water quality third edition, vol 1, Recommendations. WHO, 2008.

14. Guidelines for drinking Water quality second edition, vol 2; Health criteria and other supporting information,WHO.1996.

15. https://www.kru-gjakova.com

16. Statistical Office of Kosova 2015, Demografic data.

17. Edberg S.C. Rice, E.W. Karlin, R.J.\& Allen M.2000; Escherichia coli; the best biological drinking water indicator for public health protection. Journal of Applied Microbiology 88.106-116 
18. Abdolmajid Fadaei, Mehraban Sadeghi; Evaluation and Assessment of Drinking Water Quality in Shahrekord, Iran; Resources and Environment 2014, 4(3);168-172

19. Hassane Adamou, Boubacar Ibrahim, Seyni Salack, Rabani Adamou, Safietou Sanfo and Stefan Liersch; Physico-chemical and bacteriological quality of ground water in a rural area of Western Niger:A case study of Bonkoukou; Journal and Water and Health;2020;77-90

20. Chippaux, J. P., Houssier, S., Gross,P., Bouvier,C \& Brissaud, F; Study on groundwater pollution in the city of Niamey,Niger;Buletin de la Societe de pathologie exotiques 94 (2),(2002),119-123

21. Bricha, S., Ounine, K.,Oulkheir, S.,Haloui N,E,L \& Attarasi, B,2007;Study of the physicochemical and bacteriological quality of the M'nasra groundwater (Marocco).Afrique Science 3 (2),391-404.

22. Dougna, A. A., Gnazou, M.D.T., Kodom, T., Djaneye-Boundjou, G \& Bawa, M. L.2015;Physico -chemistry and water quality in village hydraulic boreholes in central region og Togo);International Journal of Biological and Chemical Sciences 9 (4),2249-2262.

23. Zabed, H., Suely, A., Faruq, G., Sahu, J,N., 2014.Water Quality Assessment of an unusual ritual well in Bangladesh and impact of mass bathing on this quality, Science of the Total Environment, 472,363-369.

24. Kumar, A.; Chang, B.; Xagoraraki, I. Human health risk assessment of pharmaceuticals in water: Issues and challenges ahead. Int. J. Environ. Res. Public Health 2010, 7, 3929-3953. [CrossRef] [PubMed]

25. Majuru B, Suhrcke M, Hunter P. How Do Households Respond to Unreliable Water Supplies? A Systematic Review. Int. J. Environ. Res. Public Health 2016, 13, 1222.

26. Ridpath A, Taylor E, Greenstreet C, et al. Description of calls from private well owners to a national well water hotline, 2013. Sci Total Environ. 2016 February 15; 544: 601-605.

27. Abia A, Schaefer L, Jaswa E, Le Roux W. Abundance of Pathogenic Escherichia coli Virulence-Associated Genes in Well and Borehole Water Used for Domestic Purposes in a Peri-Urban Community of South Africa. Int. J. Environ. Res. Public Health 2017, 14, 320.

28. Maran N, Crispim B, lahnn S, et al. Depth and Well Type Related to Groundwater Microbiological Contamination. Int. J. Environ. Res. Public Health 2016, 13, 1036.

29. Nayra Halimy Maran,Bruno do Amaral Crispim,Stephanie Ramirez Lahnn,Renata Pires de Araunjo,Alexia Baruffatti Grisolia and Kelly Mari Pires de Oliveira ;Depth and well type related to groundwater microbiological contamination; International Journal of Environmental Research and Public Health ,2016

30. S. Maysarah et al: To occurrence of Escherichia coli in groundwater of Begasi City (Case stydy:Jatiluhur,Sumur Batu and Jatirangga urban Villages),Earth Environment.Sci.566,2020

31. Camila Bolognes Couto Pahl, Giancarlo Lastoria and Sandra Garcia Gabas; Microbial contamination of groundwater in swine fertigation area; Brasilian Journal of water resource,2018.

32. Abok Elisha Onyango,Michael Wandayi ,Catherine Nkirote Kunyanga and Bernard Ochieng Aliwa: Microbiological Quality and Contamination on level of water sources in Isido country in Kenya; Journal of Environmental and Public Health,2018.

33. Akebe Luther king Abia, Lisa Schafer, Eunice Ubomba -Jaswa and Water Le Roux: Abundance of pathogenic Escherichia Coli virulence-Associated genes in well and Borehole water use for domestic purposes in e Peri-Urban Community of South Africa; Environment. Research and Public Health, 2017. 
Journal of Science, Humanities and Arts

34. Jeremiah Kasalku Takal \& Jonathan Arthur Quaye- Ballard; Bacteriological contamination of groundwater in relation to septic tanks location in Ashanti region, Ghana; Cogent Environmental Science, (2018),4:1556197

35.Rai S.K., Ono K., Yanagida J.I., Ishiama-Imura S., Kurokawa M., Rai.C.K., Nepal Med Coll J 14 (3) (2012) 234-240. 


\section{About the Author}

Prof Ass Dr. Antigona Ukëhaxhaj,had finished Medical Faculty at the University of Prishtina, where she also got a Master science degree in Public Health. During the work in National Institute of Public Health of Kosovo, she is specialised in Hygiene. Being related and interested in public health she participated in many workshops, conferences and projects in Public Health area.PhD study she finished at University of "Kirij i Metodij" of Skopje; FYROM. She is Professor Assistant at the University of Gjakova and also Vice Dean in Medical Faculty in University of Gjakova. She works from 1999 at Centre for Laboratory Testing at National Institute of Public Health too. Her expertise includes water quality monitoring, environmental pollution and public health. 